\title{
Job crafting, proactive personality and meaningful work: Implications for employee engagement and turnover intention
}

\begin{tabular}{|c|c|}
\hline \multicolumn{2}{|c|}{$\begin{array}{l}\text { Authors: } \\
\text { Nicola Vermooten }{ }^{1} \\
\text { Billy Boonzaier } \\
\text { Martin Kidd }\end{array}$} \\
\hline \multicolumn{2}{|c|}{$\begin{array}{l}\text { Affiliations: } \\
{ }^{1} \text { Department of Industrial } \\
\text { Psychology, Stellenbosch } \\
\text { University, Stellenbosch, } \\
\text { South Africa }\end{array}$} \\
\hline \multicolumn{2}{|c|}{$\begin{array}{l}{ }^{2} \text { Centre for Statistical } \\
\text { Consultation, and } \\
\text { Department of Statistics and } \\
\text { Actuarial Sciences, } \\
\text { Stellenbosch University } \\
\text { Stellenbosch, South Africa }\end{array}$} \\
\hline \multicolumn{2}{|c|}{$\begin{array}{l}\text { Corresponding author: } \\
\text { Nicola Vermooten, } \\
\text { nicolavanderwest@gmail.com }\end{array}$} \\
\hline \multicolumn{2}{|c|}{$\begin{array}{l}\text { Received: } 18 \text { July } 2018 \\
\text { Accepted: } 01 \text { Mar. } 2019 \\
\text { Published: } 30 \text { July } 2019\end{array}$} \\
\hline \multicolumn{2}{|c|}{$\begin{array}{l}\text { How to cite this article: } \\
\text { Vermooten, N., Boonzaier, B., } \\
\text { \& Kidd, M. (2019). Job } \\
\text { crafting, proactive personality } \\
\text { and meaningful work: } \\
\text { Implications for employee } \\
\text { engagement and turnover } \\
\text { intention. SA Journal of } \\
\text { Industrial Psychology/SA } \\
\text { Tydskrif vir Bedryfsielkunde, } \\
45(0), \text { a1567. https://doi. } \\
\text { org/10.4102/sajip.v45i0.1567 }\end{array}$} \\
\hline \multicolumn{2}{|c|}{$\begin{array}{l}\text { Copyright: } \\
\text { (c) 2019. The Authors } \\
\text { Licensee: AOSIS. This } \\
\text { is licensed under the } \\
\text { Creative Commons } \\
\text { Attribution License. }\end{array}$} \\
\hline \multicolumn{2}{|l|}{ Read online: } \\
\hline 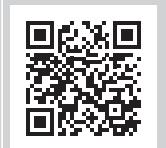 & $\begin{array}{l}\text { Scan this QR } \\
\text { code with your } \\
\text { smart phone or } \\
\text { mobile device } \\
\text { to read online. }\end{array}$ \\
\hline
\end{tabular}

Orientation: Jobs in the financial services industry are in constant flux because of the everchanging nature of the products and services provided to customers. This could result in employee disengagement and turnover intention.

Research purpose: The purpose of the study was to examine the role of job crafting, proactive personality and meaningful work in predicting employee engagement and turnover intention among employees in the financial services industry based on the central tenets of the Job Demands-Resources theory.

Motivation for the study: Organisations or incumbents may redesign jobs. The self-initiated proactive behaviour that incumbents exhibit to shape the meaning of their work is known as job crafting. The relationships that exist among job crafting, proactive personality, meaningful work, employee engagement and turnover intention were, therefore, investigated.

Research design, approach and method: A quantitative cross-sectional survey design was used to gather primary data in service-providing firms across South Africa $(n=391)$.

Main findings: Results demonstrated that job crafting, proactive personality and meaningful work significantly predict variance in employee engagement and turnover intention.

Practical and managerial implications: Specific human resource practices and interventions are proffered to foster job crafting, proactivity and meaningful work and, in doing so, address employee disengagement and turnover intention.

Contribution or value-add: The study highlights the importance of encouraging employees to craft their jobs as it has specific implications for prominent work-related outcomes, such as employee engagement and turnover intention, among employees in the financial services industry.

Keywords: Positive psychology; web-based survey; proactive personality scale; job crafting scale; psychological meaningfulness scale; Utrecht work engagement scale; turnover intention scale; covariance structural equation modelling; partial least squares structural equation modelling.

\section{Introduction}

Research has shown that employees perform optimally in challenging, resourceful work environments, as these environments foster employee engagement (Bakker \& Demerouti, 2014). Organisations in the financial services industry should, therefore, develop and implement human resource practices and interventions that influence the work conditions (i.e. job demands and job resources) of their employees. In addition, the researchers argue that it is just as important for employees themselves to adjust their work conditions proactively. This can be achieved through crafting behaviour (i.e. job crafting) (Wrzesniewski \& Dutton, 2001).

Job crafting is the process whereby employees, through their personal initiative, adjust their work environment to ensure that their need for congruence with their environment is met and to improve the meaningfulness of their work-related activities (Wrzesniewski \& Dutton, 2001). As opposed to other bottom-up but reactive approaches to job redesign (e.g. employee participation in job redesign), job crafting denotes a self-initiated proactive work behaviour (Crant, 1995).

According to Parker and Collins (2010), proactive work behaviours involve taking action to address foreseeable situations at work in advance or taking control and effecting change in the 
work environment. Research has shown that employees who have a disposition towards proactive behaviour (i.e. proactive personality) are more inclined to exhibit proactive work behaviours than their counterparts (McCormick, Guay, Colbert, \& Stewart, 2018). It is, therefore, proposed that job crafting, proactive personality and meaningful work are salient antecedents of variance in prominent work-related outcomes, such as employee engagement and turnover intention.

\section{Research purpose and objectives}

Against this background, the purpose of the study was to examine the role of job crafting, proactive personality and meaningful work in predicting employee engagement and turnover intention among employees in the financial services industry within the framework of the Job DemandsResources (JD-R) theory. More specifically, the study aimed to:

- determine the level of employee engagement and turnover intention among employees in service-providing firms that operate in the financial services industry;

- propose and empirically test an explanatory employee engagement and turnover intention structural model among employees in service-providing firms that operate in the financial services industry;

- highlight the managerial implications of results, and recommend specific human resource practices and interventions to address challenges pertaining to employee engagement and turnover intention among employees in service-providing firms that operate in the financial services industry.

\section{Literature review}

\section{Job Demands-Resources theory}

The JD-R theory is a meta-theoretical framework that can be applied to diverse occupational settings. Even though each occupation has a unique set of work characteristics that are associated with employee wellness and effectiveness, the JD-R theory suggests that these characteristics can be categorised as job demands or job resources (Demerouti, Bakker, Nachreiner, \& Schaufeli, 2001).

Job demands are the physical, psychological, social or organisational features of a job that require sustained physical, mental and/or psychological (i.e. cognitive and emotional) effort from employees (e.g. job insecurity or role conflict). Notably, job demands do not necessarily incur physiological and/or psychological costs. These characteristics evoke strain only when they exceed the adaptive capability of employees. Job resources, on the other hand, are the physical, psychological, social or organisational features of a job that enable employees to reduce job demands, achieve work goals, and stimulate development, learning and personal growth (Tims \& Bakker, 2010). These characteristics are found at an organisational level (e.g. opportunities for advancement), an interpersonal level (e.g. team processes), a task level (e.g. feedback) or the level of work design (e.g. autonomy) (Demerouti \& Bakker, 2011).

The JD-R theory suggests that two different underlying psychological processes influence the development of job strain (i.e. burnout) on the one hand and motivation (i.e. employee engagement) on the other. These processes reflect a health impairment process and a motivational process. The health impairment process (or effort-driven process) assumes that demanding jobs or jobs with chronic demands incur physiological and/or psychological costs by exhausting employees' physical and mental resources. This, in turn, may lead to health problems and the depletion of their energy. The motivational process (or motivation-driven process), on the other hand, assumes that job resources are not only used to deal with job demands but may be valued in their own right (i.e. intrinsic motivation) or may help employees achieve or protect other valued resources (i.e. extrinsic motivation) as well. By implication, these characteristics possess motivation potential that may foster employee engagement, improve job performance and discourage cynicism. Empirical research has demonstrated support for both processes (Bakker \& Demerouti, 2014; Demerouti \& Bakker, 2011).

Even though the JD-R theory was initially restricted to work conditions (i.e. job demands and job resources), Xanthopoulou, Bakker, Demerouti and Schaufeli (2007) highlighted that personal resources (e.g. optimism or selfefficacy) are also important determinants of employees' adaptive capability. These researchers defined personal resources as 'aspects of the self that are generally linked to resiliency and refer to individuals' sense of their ability to control and influence their environment successfully' (p. 123). Their cross-sectional study among 714 Dutch employees from an electrical engineering and electronics organisation showed support for this notion and demonstrated that personal resources mediate the positive association between job resources and employee engagement (i.e. motivational process) and influence employees' perception of job resources.

\section{Job crafting}

Parker and Ohly (2008) proposed that employees could actively shape their job design from the bottom up. This employee-driven process, known as job crafting, was initially defined as cognitive and physical changes employees make to the relational or task boundaries of their job (Wrzesniewski \& Dutton, 2001). However, this definition of job crafting offered a limited perspective of the construct. To address concerns with the above-mentioned definition of job crafting, Tims, Bakker and Derks (2012) proposed that it involves self-initiated changes that employees make to their work conditions (i.e. job demands and job resources) in accordance with the JD-R theory. More specifically, these researchers proposed that job crafting involves increasing social or structural job resources, as well as challenging (positive) job demands, and/or decreasing hindrance stressors that interfere with work performance. 
By drawing on the central precepts of the JD-R theory, the researchers operationalised proactive personality as a personal resource and meaningful work as a job resource among employees in the financial services industry.

\section{Proactive personality}

All humans have a unique personality characterised by a set of distinct personality traits. These traits signify the dimensions along which humans' personalities vary in relatively stable ways (Roberts et al., 2017). According to Barrick, Mount and Li (2013), personality traits are distal motivational forces that can be used to make generalisations about human nature and explore between-person differences, as they determine humans' behavioural responses. The researchers argue that proactive personality represents an invaluable personal resource among employees in the financial services industry.

Proactive personality refers to a 'relatively stable tendency to effect environmental change' (Bateman \& Crant, 1993, p. 103). In other words, it denotes a dispositional tendency to engage in proactive behaviour. While some employees adapt to, react to and are shaped by their work environment, employees who have a proactive personality recognise opportunities, take personal initiative and persevere until they have brought about meaningful change in their work environment (Bakker, Tims, \& Derks, 2012).

By drawing on the theory of proactive personality (Bateman \& Crant, 1993), the researchers propose that employees who have a proactive personality, would be more inclined to exhibit crafting behaviour. More specifically, employees who have a proactive personality are more inclined to increase social or structural job resources and challenging job demands, and decrease hindering job demands. Research has shown direct support for the positive association between proactive personality and job crafting. For example, a cross-sectional study conducted by Bakker et al. (2012) among 95 dyads ( $n=$ 190) in the Netherlands found that employees who have a proactive personality were more inclined to craft their jobs (i.e. increasing structural or social job resources and challenging job demands). Comparable results were reported by Plomp et al. (2016) among a heterogeneous group of 574 employees and by Zhang, Lu and Li (2018) among 1971 employees. Based on a review of the existing literature, the researchers formulated the following hypothesis:

H1: Proactive personality has a significant positive influence on job crafting (i.e. increasing social or structural job resources and challenging job demands, and decreasing hindering job demands).

\section{Turnover intention}

Employee turnover involves the voluntary movement of employees across the membership boundaries of organisations (Price, 2001). It occurs when employees decide to depart from their current organisation despite having the opportunity of continued employment. Notably, employee turnover is a multistage process. Turnover intention is the last sequence of withdrawal cognitions in the turnover process (Parker \& Martin, 2009). Although turnover intentions may not necessarily lead to employee turnover, research has indicated that it represents an important outcome variable (Chang, Wang, \& Huang, 2013).

Research has revealed that employees who have a proactive personality strive for congruence between themselves and their work environment in terms of their needs and abilities (Parker \& Collins, 2010; Tims \& Bakker, 2010). The researchers argue that this might be compounded by their inclination to adopt proactive work behaviours. If their need for congruence with their work environment is not met, employees with a proactive personality may be more inclined, because of their inclination to adopt proactive work behaviours, to seek alternative employment opportunities. As opposed to tolerating a frustrating work environment, these employees may respond to the lack of congruence between themselves and their work environment by developing turnover intention. For this reason, the researchers formulated the following hypothesis:

H2: Proactive personality has a significant positive influence on turnover intention.

\section{Meaningful work}

Adlerian theory proposes that all humans live in the realm of meanings (Alderfer, 1972). They experience their reality by attaching meaning to experiences through the process of meaning-making. According to Mezirow (1981, p. 394), 'at its simplest meaning-making refers to a lifelong process of understanding the world and our relationships with it'. Through the interpretation of their experiences, humans spin webs of meaning known as 'meaning systems' (Molden \& Dweck, 2006, p. 201). These integrated mental representations of interrelations between objects, events and relationships encompass everything humans know.

In light of the preceding discussion, it is to be expected that employees seek meaning in their work experiences. It is, however, necessary to recognise that considerable differences exist in the way employees perceive their work (Wrzesniewski, McCauley, Rozin, \& Schwartz, 1997). Job design alone does not determine the meaningfulness of work (Steger, Dik, \& Duffy, 2012; Tims, Derks, \& Bakker, 2016). Inherent in the existence of meaningful work are job design (e.g. task significance and comprehensibility), person-job fit (e.g. values and mission), work relationships (e.g. colleagues and supervisors) and work beliefs (e.g. calling orientation) (Pratt \& Ashforth, 2003). Wrzesniewski (2003) proposed that employees can improve the meaningfulness of their work by aligning it with their perception of work through job crafting.

A three-wave study conducted by Tims et al. (2016) among a heterogeneous group of 114 employees in the Netherlands has examined whether job crafting and meaningful work are positively related. These researchers demonstrated that employees who engaged in job crafting in the first week 
(i.e. increasing social or structural job resources and challenging job demands, and decreasing hindering job demands) reported higher levels of person-job fit the following week and, in turn, found their work more meaningful in the final week. In line with this, Wrzesniewski, LoBuglio, Dutton and Berg (2013) suggested that job crafting is related to work meaning and identity. This suggests that job crafting optimises person-job fit and, in turn, enhances the meaningfulness of work. In line with the above, the researchers formulated the following hypothesis:

H3: Job crafting (i.e. increasing social or structural job resources and challenging job demands, and decreasing hindering job demands) has a significant positive influence on meaningful work.

\section{Employee engagement}

Employee engagement has attracted much attention from researchers and practitioners alike. Perhaps this is to be expected given that it is considered a key determinant of organisational success (Macey, Schneider, Barbera, \& Young, 2009; Rich, LePine, \& Crawford, 2010). Despite being one of the most popular constructs in the research field of industrial and organisational psychology, there is still a lack of agreement about its definition and meaning. In this study, employee engagement is defined in accordance with Schaufeli, Salanova, González-Romá and Bakker (2002).

Schaufeli et al. (2002, p. 74) define employee engagement as 'a positive, fulfilling, work-related state of mind that is characterised by vigour, dedication, and absorption'. These researchers describe it as a relatively persistent and pervasive affective-cognitive state that does not depend on specific objects, events, individuals or behaviours. They suggest, in contrast to early studies (e.g. Maslach \& Leiter, 1997) which conceptualised burnout and engagement as opposite poles of a continuum, that burnout and engagement are independent concepts (that should be measured with different instruments).

Apart from the positive association between job crafting and meaningful work, the study propose that employees who consider their work meaningful are more inclined to invest themselves in their work and engage more fully. Because of the intrinsic motivational force associated with meaningful work, these employees may find it easier to approach their work-related activities with vigour, dedication and absorption. Research has shown direct support for the positive association between meaningful work and employee engagement (Shuck, 2019). As an illustration, a cross-sectional study conducted by Jung and Yoon (2016) among 352 employees from family-style restaurants and 5-star hotels in South Korea demonstrated that employees who considered their work to be meaningful were engaged in their work. In line with this, Steger, Littman-Ovadia, Miller, Menger and Rothmann (2013) demonstrated that meaningful work and employee engagement were positively related among a heterogeneous group of 252 white-collar employees in Israel. Comparable results were reported by Geldenhuys, Łaba and
Venter (2014) among a heterogeneous group of 415 employees in South Africa. The researchers consequently formulated the following hypothesis:

H4: Meaningful work has a significant positive influence on employee engagement.

In line with hypothesis 4 , the researchers propose that employees who consider their work meaningful are less inclined to quit their job in the near future. Because of the presence of the intrinsic motivational force associated with meaningful work, these employees may be less inclined to seek alternative employment opportunities.

Research has revealed support for the negative association between meaningful work and turnover intention. As an illustration, a cross-sectional study conducted by Janik and Rothmann (2015) demonstrated that meaningful work and turnover intention were negatively related among 502 secondary school teachers in Namibia. Comparable results were reported by Arnoux-Nicolas, Sovet, Lhotellier, Di Fabio and Bernaud (2016) among a heterogeneous group of 336 employees in France and by Sun, Lee and Sohn (2019) among 315 employees in South Korea. For this reason, the researchers formulated the following hypothesis:

H5: Meaningful work has a significant negative influence on turnover intention.

Meta-analytic evidence reported by Bakker, Hakanen, Demerouti and Xanthopoulou (2007) showed that job resources and employee engagement were positively related, especially when job demands were high. By implication, when employees, who face high job demands, have sufficient job resources they are still able to flourish in their work. With this in mind, the researchers proffered that employees who exhibit crafting behaviour are more inclined to be engaged in their work as they adjust their work conditions (i.e. job demands and job resources) proactively. Job crafting, therefore, represents a practical way in which emplyees themselves can enhance their own work engagement.

Research has shown direct and indirect support for the above-mentioned process of 'self-engagement' (Bakker et al., 2012, p. 1363). As an example, a cross-sectional study conducted by Hakanen, Bakker and Schaufeli (2006) among 2555 Finish dentists found that personal initiative and employee engagement were positively related. Similarly, a cross-sectional study conducted by Hyvönen, Feldt, SalmelaAro, Kinnunen and Mäkikangas (2009) among 747 Finnish managers found that managers who wanted to expand their professional knowledge and develop themselves on the job were engaged in their work. Comparable results were reported by Harju, Hakanen and Schaufeli (2016) among 1630 educated employees in Finland and by Mäkikangas (2018) among 131 Finish rehabilitation workers. Consequently, the researchers formulated the following hypothesis:

H6: Job crafting (i.e. increasing social or structural job resources and challenging job demands, and decreasing hindering job demands) has a significant positive influence on employee engagement. 
Notably, Bakker (2011) suggested that the positive association between employee engagement and job crafting may be dynamic. He proposed that apart from the positive association between job crafting and employee engagement, it is plausible that a recerse causal association also exists between these constructs. Drawing on the Broaden-andBuild theory of positive emotions (Fredrickson, 2004), the researchers support this notion. The Broaden-and-Build theory proposes that positive emotions broaden employees' momentary thought-action repertoire (i.e. broaden hypothesis). As their momentary thought-action repertoire broadens, employees build personal resources that range from psychological and social resources to intellectual and physical resources (i.e. build hypothesis). In contrast, negative emotions narrow the momentary thought-action repertoire of employees (Fredrickson, 2004). A study conducted by Schaufeli and Van Rhenen (2006) among 815 managers from a telecommunications organisation in the Netherlands showed that engaged employees experienced positive emotions. In view of this, the current researchers support the notion that the positive emotions (including vigour, dedication and absorption) that engaged employees experience broaden their momentary thought-action repertoire and, in turn, encourage job crafting.

Research has revealed direct and indirect support for the reverse causal association between job crafting and employee engagement. For example, a diary study conducted by Sonnentag (2003) among 147 employees from public service organisations in Germany demonstrated that day-level employee engagement was positively associated with day-level proactive behaviour (i.e. the pursuit of learning and personal initiative) during the following work day. In accordance with this, Fritz and Sonnentag (2009) found that positive affective experiences were related to proactive behaviours (i.e. personal initiative) among 172 employees from civil service organisations in Germany. Harju et al. (2016) demonstrated direct support for this notion among 1630 educated employees in Finland. More specifically, they found that engaged employees were more inclined to exhibit crafting behaviour (i.e. increasing social or structural job resources). Comparable results were reported by Hakanen, Peeters and Schaufeli (2018) among 1877 dentists in Finland. The following hypothesis was consequently formulated in the study:

H7: Employee engagement has a significant positive influence on job crafting (i.e. increasing social or structural job resources and challenging job demands, and decreasing hindering job demands).

Apart from encouraging job crafting, the positive emotions (specifically vigour and dedication) that engaged employees experience may cultivate a sense of organisational commitment and, in turn, discourage the development of turnover intention. The researchers offer the Conversion of Resources theory (Hobfoll, 1989) to support this notion. The Conversion of Resources theory proposes that employees invest resources in their work environment and seek to minimize the loss of resources. Engaged employees willingly commit themselves to their work (i.e. dedication) and have difficulty detaching themselves after tasks have been completed (i.e. absorption) thereby investing resources in their current organisation (Schaufeli et al., 2002). In consideration of this, the researchers advocated that engaged employees are less inclined to seek alternative employment opportunities. The loss of resources that is associated with starting work in a new organisation discourages these employees to develop turnover intentions.

Research has shown direct support for the negative association between employee engagement and turnover intention. Meta-analytic evidence reported by Halbesleben (2010) and Saks (2019) found that employees who exhibit vigour and dedication were less inclined to develop turnover intention. In accordance with this, Takawira, Coetzee and Schreuder (2014) demonstrated that dedication and turnover intention were negatively related among 153 academic and non-academic employees from a higher education institution in South Africa. Comparable results were reported by Gabel Shemueli, Dolan, Suárez Ceretti and Nuñez Del Prado (2016) among 818 nurses in Uruguay $(n=316)$ and Spain $(n=502)$ and by Agarwal and Gupta (2018) among 1302 heterogenous managers in India. For this reason, the researchers formulated the following hypothesis:

H8: Employee engagement has a significant negative influence on turnover intention.

\section{Research design}

Research approach

The researchers adopted a quantitative research approach based on correlational analysis to achieve the research objectives. More specifically, primary data were collected through a cross-sectional survey of job crafting, proactive personality, meaningful work, employee engagement and turnover intention.

\section{Research method}

\section{Research participants}

The setting for the study comprised organisations in the financial services industry. Three service-providing firms that operate in the financial services industry were invited to participate in the study. Each firm, with regional offices across South Africa, was part of an international service provider offering primarily auditing and accounting services.

The researchers used non-probability purposive sampling to select a sample of approximately 800 employees from participating regional offices. Three hundred and ninety-one employees participated in the study (49\% response rate). Table 1 offers a description of the demographic and employment characteristics of participants. 
Data showed that women comprised $61 \%$ of the sample. The majority of participants had completed an Honour's degree (highest level of education; 70\%), were employed less than a year at their current service-providing firm (organisational tenure; 34\%) and worked in the auditing department (department; 82\%). Furthermore, the age of participants varied from 18 to 57 years (mean = 26.53 years).

\section{Measuring instruments}

The web-based survey comprising two sections was developed specifically for the study. The first section requested the demographic and employment information of participants and the second section measured the latent variables of interest.

\section{Proactive Personality Scale}

Proactive personality was measured with the abbreviated Proactive Personality Scale (Claes, Beheydt, \& Lemmens, 2005). This self-report measure consists of six items. An example item is 'If I see something I don't like, I fix it'. A cross-cultural analysis across three countries (i.e. Belgium, Finland and Spain) showed support for the internal consistency reliability of the abbreviated Proactive Personality Scale ( $\alpha=0.78$ to 0.86 ) (Claes et al., 2005). The abbreviated Proactive Personality Scale measured the degree to which participants had a proactive personality. A seven-point Likert-type scale varying from 1 (certainly not agree) to 7 (certainly agree) was used to score responses. No items of the abbreviated Proactive Personality Scale were reverse-scored.

\section{Job Crafting Scale}

The Job Crafting Scale (Tims et al., 2012) was used to measure job crafting. This self-report measure, which consists of 21 items, assesses the four dimensions of job crafting, namely increasing social job resources (five items,

TABLE 1: Demographic and employment characteristics of participants.

\begin{tabular}{llcr}
\hline Item & Category & Frequency & \% \\
\hline Gender & Women & 237 & 60.60 \\
& Men & 154 & 39.40 \\
Highest level of education & Matric & 35 & 8.95 \\
& Diploma & 15 & 3.84 \\
& Degree & 41 & 10.49 \\
& Honour's degree & 274 & 70.08 \\
& Master's degree & 7 & 1.70 \\
& Other (not specified) & 19 & 4.86 \\
Department & Auditing & 322 & 82.35 \\
& Consulting & 16 & 2.09 \\
& Financial advisory & 7 & 1.79 \\
& Tax & 5 & 1.28 \\
& Other (not specified) & 41 & 10.49 \\
& $<1$ year & 133 & 34.02 \\
Organisational tenure & 1 year & 31 & 7.93 \\
& 2 years & 88 & 22.51 \\
& 3 years & 55 & 14.07 \\
& $>3$ years & 84 & 21.48 \\
\hline
\end{tabular}

e.g. 'I ask others for feedback on my job performance'), increasing structural job resources (five items, e.g. 'I try to develop myself professionally'), increasing challenging job demands (five items, e.g. 'when there is not much to do at work, I see it as a chance to start new projects') and decreasing hindering job demands (six items, e.g. 'I make sure that my work is mentally less intense'). A validation study among a random sample of 375 employees in the Netherlands (Tims et al., 2012) demonstrated support for the internal consistency reliability of the subscales of the Job Crafting Scale (increasing social job resources: $\alpha=0.77$; increasing structural job resources: $\alpha=0.82$; increasing challenging job demands: $\alpha=0.75$; decreasing hindering job demands: $\alpha=0.79$ ). The four subscales of the Job Crafting Scale were combined in the study. The composite measurement indicator measured the degree to which participants engaged in crafting behaviour. A five-point Likert-type scale varying from 1 (never) to 5 (often) was used to score responses. No items of the Job Crafting Scale were reverse-scored.

\section{Psychological Meaningfulness Scale}

Meaningful work was measured with the Psychological Meaningfulness Scale (May, Gilson, \& Harter, 2004). This self-report measure consists of six items. An example item is 'I feel that the work I do on my job is valuable'. A validation study among 213 employees from an insurance firm in the United States of America (US) demonstrated support for the internal consistency reliability of the Psychological Meaningfulness Scale $(\alpha=$ 0.90) (May et al., 2004). The Psychological Meaningfulness Scale measured the degree of meaning that participants in the study found in their work-related activities. A fivepoint Likert-type scale varying from 1 (strongly disagree) to 5 (strongly agree) was used to score responses. No items of the Psychological Meaningfulness Scale were reversescored.

\section{Utrecht Work Engagement Scale}

The Utrecht Work Engagement Scale (UWES-9) (Schaufeli, Bakker, \& Salanova, 2006) was used to measure employee engagement. This self-report measure, which consists of nine items, assesses the three dimensions of employee engagement, namely vigour (three items, e.g. 'at my work, I feel bursting with energy'), dedication (three items, e.g. 'I am enthusiastic about my job') and absorption (three items, e.g. 'I am immersed in my work'). A cross-cultural analysis across 10 countries (i.e. Australia, Belgium, Canada, Finland, France, Germany, the Netherlands, Norway, South Africa and Spain) showed support for the internal consistency reliability of the UWES-9 $(\alpha=0.85-0.92)$ and its subscales (vigour: $\alpha=0.60-0.88$; dedication: $\alpha=0.75-0.90$; absorption: $\alpha=0.66-0.86$ ) (Schaufeli et al., 2006). The three subscales of the UWES-9 were combined in the study. The composite measurement indicator measured the degree to which participants were engaged in their work. A seven-point 
Likert-type scale varying from 0 (never) to 6 (always or everyday) was used to score responses. No items of the UWES-9 were reverse-scored.

\section{Turnover Intention Scale}

Turnover was measured with the Turnover Intention Scale (Moore, 2000). This self-report measure consists of four items. An example item is 'I will probably look for a job at a different company in the next year'. A validation study among a random sample of 214 employees in the US demonstrated support for the internal consistency reliability of the Turnover Intention Scale $(\alpha=0.92)$ (Moore, 2000). The Turnover Intention Scale measured the probability that participants would quit their job in the near future. A five-point Likert-type scale varying from 1 (very unlikely) to 5 (very likely) was used to score responses. Two items of the Turnover Intention Scale were reverse-scored.

\section{Research procedure}

Once the study was evaluated and approved by the Ethics Committee of the university where the research was undertaken, the researchers approached the human resource managers of financial service-providing firms with regional offices across South Africa. The human resource managers received an email that contained a letter of approval from abovementioned Ethics Committee and an institutional permission form. Human resource managers who agreed to participate in the study were asked to send a signed copy of the institutional permission form to the principal researcher. This gave the researchers written permission to invite employees to complete the web-based survey.

The web-based survey was sent electronically to employees of participating regional offices. Participation was anonymous and voluntary. Informed consent was obtained from individual participants. Participants were given 3 weeks to complete the survey. Two reminders (i.e. weekly) were sent to employees to encourage their participation.

\section{Statistical analysis}

A number of statistical procedures were used to analyse the data and to evaluate the proposed employee engagement and turnover intention structural model, depicted in Figure 1. These techniques included item analysis to determine the reliability of the latent variable scales, confirmatory factor analysis to validate the measurement model and covariance-based Structural Equation Modelling (SEM) to evaluate the structural model. In addition, partial least squares (PLS) SEM, a prediction-oriented SEM technique, was performed as an alternative method to evaluate the structural model.

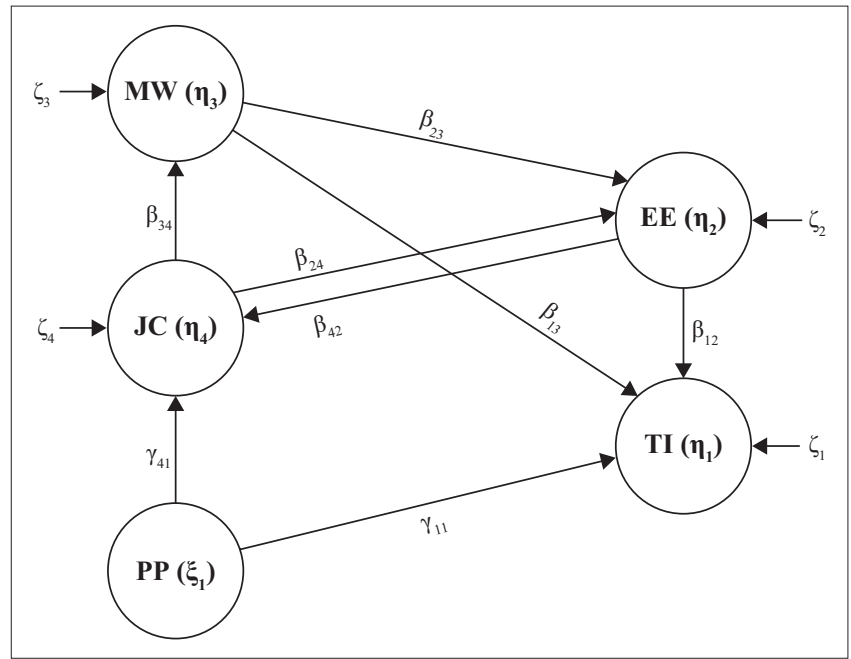

Note: It was assumed that the structural error terms were fixed to zero.

$\xi_{1}$, proactive personality; $\eta_{1}$, turnover intention; $\eta_{2}$, employee engagement; $\eta_{3}$, meaningful work; $\eta_{4^{\prime}}$ job crafting.

FIGURE 1: Proposed employee engagement and turnover intention structural model.

TABLE 2: Psychometric properties of measuring instruments.

\begin{tabular}{lccccc}
\hline Scale & $\begin{array}{c}\text { Number } \\
\text { of items }\end{array}$ & $\begin{array}{c}\text { Cronbach's } \\
\text { alpha }\end{array}$ & $\begin{array}{c}\text { Average inter-item } \\
\text { correlation }\end{array}$ & Mean & $\begin{array}{c}\text { Standard } \\
\text { deviation }\end{array}$ \\
\hline PPS (PP) & 6 & 0.83 & 0.45 & 5.65 & 0.82 \\
JCS (JC) & 21 & 0.87 & 0.26 & 3.58 & 0.51 \\
PMS (MW) & 6 & 0.94 & 0.74 & 3.89 & 0.82 \\
UWES-9 (EE) & 9 & 0.93 & 0.60 & 3.92 & 0.97 \\
TIS (TI) & 4 & 0.85 & 0.60 & 2.66 & 1.12 \\
\hline
\end{tabular}

PPS, proactive personality scale; PP, proactive personality; JCS, job crafting scale; JC, job crafting; PMS, psychological meaningfulness scale; MW, meaningful work; UWES-9, Utrech work engagement scale; EE, employee engagement; TIS, turnover intention scale; TI, turnover intention.

\section{Ethical consideration}

Ethical approval was received from the Stellenbosch University Research Ethics Committee: Human Research (Humanities). Ref. nr: DESC_VanderwesthuizenN2013.

\section{Results}

\section{Testing the measurement model}

\section{Item analysis}

An item analysis was done on each latent variable scale that was included in the web-based survey. Table 2 shows that the Cronbach's alpha for each latent variable scale were satisfactory ( $\geq 0.70$ ) (Nunnally, 1978). Moreover, the average inter-item correlation of the Psychological Meaningfulness Scale, UWES-9 and Turnover Intention Scale was > 0.50. Even though the average inter-item correlation for the abbreviated Proactive Personality Scale and Job Crafting Scale was 0.45 and 0.26 , respectively, this was still considered satisfactory ( $\geq 0.15$ ) (Clark \& Watson, 1995).

\section{Evaluating measurement model fit}

Confirmatory factor analysis was performed to evaluate the measurement model fit. Notably, the researchers did not test all the model parameters in a single measurement model. Three measurement models were constructed. These measurement models were the employee engagement measurement model, the job crafting measurement model, 
and the meaningful work, proactive personality and turnover intention measurement model.

Results showed that the empirical data reproduced the employee engagement measurement model reasonably well: Sattora Bentler chi-square value $=85.84(p<0.00)$, root mean square error of approximation (RMSEA) value $=0.08$, goodness-of-fit index (GFI) value $=1.00$ and adjusted goodness-of-fit index (AGFI) value $=0.99$. The factor loadings of the indicator variables, which were included in the employee engagement measurement model, were statistically significant $(p<0.05)$ and the $t$-values exceeded the critical cut-off values $(-1.96<t$-value $<+1.96)$. The factor loadings ranged from 0.71 to 0.97 , and $t$-values ranged from 18.68 to 96.16 .

Comparable results were reported for the job crafting measurement model. The job crafting measurement model was also reproduced reasonably well by the empirical data: Sattora Bentler chi-square value $=480.41(p<0.00)$, RMSEA value $=0.07$, GFI value $=0.97$ and AGFI value $=0.97$. The factor loadings of the indicator variables, which were included in the job crafting measurement model, were statistically significant $(p<0.05)$ and the $t$-values exceeded the critical cut-off values $(-1.96<t$-value $<+1.96)$. The factor loadings ranged from 0.58 to 0.93 , and $t$-values ranged from 8.61 to 38.13 .

In line with the above results, the meaningful work, proactive personality and turnover intention measurement model also reproduced by the empirical data reasonably well: Sattora Bentler chi-square value $=277.41(p<0.00)$, RMSEA value $=0.07$, GFI value $=0.92$ and AGFI value $=0.89$. The factor loadings of the indicator variables, which were included in proactive personality, meaningful work and turnover intention measurement model, were statistically significant $(p<0.05)$ and the $t$-values exceeded the critical cut-off values $(-1.96<t$-value $<$ $+1.96)$. The factor loadings ranged from 0.53 to 0.92 , and $t$-values ranged from 13.03 to 93.33 .

Empirical data thus corroborate the three measurement models reasonably well. Each measurement model showed reasonable fit $(0.05<$ RMSEA $<0.08)$ and met the criteria for the GFI value ( $>0.90)$. The factor loadings of the indicator variables, which were included in each of the measurement models, were statistically significant $(p<0.05)$ and the $t$-values exceeded the critical cut-off values $(-1.96<$ $t$-value $<+1.96)$.

\section{Testing the structural model}

\section{Fitting the employee engagement and turnover intention structural model}

It is important to mention that the subscales of the Job Crafting Scale (Tims et al., 2012) and the UWES-9 (Schaufeli et al., 2006) were operationalised as manifest variables of job crafting and employee engagement, respectively, during covariance-based SEM. This enabled the researchers to fit the employee engagement and turnover intention structural model despite restrictions in terms of sample size $(n=391)$.
TABLE 3: Factor loadings of hypothesised relationships.

\begin{tabular}{lcccc}
\hline Variable & PP & JC & MW & EE \\
\hline PP & - & - & - & - \\
JC & $0.73^{*}$ & - & - & 0.05 \\
MW & - & $0.34^{*}$ & - & - \\
EE & - & $0.29^{*}$ & $0.67^{*}$ & - \\
TI & 0.12 & - & -0.01 & $-0.50^{*}$ \\
\hline
\end{tabular}

$\mathrm{PP}$, proactive personality; JC, job crafting; $\mathrm{MW}$, meaningful work; $\mathrm{EE}$, employee engagement; $\mathrm{Tl}$, turnover intention.

$*, p<0.05$ (statistically significant at the $95 \%$ confidence level).

The proposed employee engagement and turnover intention structural model, depicted in Figure 1, did not fit the empirical data exceptionally well: Sattora Bentler chi-square value $=549.22(p<0.00)$, RMSEA value $=0.06$, GFI value $=$ 0.89 and AGFI value $=0.86$. Although the RMSEA value (0.06) showed reasonable fit, this was not verified by the GFI value (0.89) and the AGFI value (0.86). These values indicated mediocre fit. To ensure the accuracy and consistency of the results obtained from subsequent statistical analyses concerning the strength and significance of the hypothesised relationships that exist among the latent variables, covariance-based SEM was supplemented with PLS SEM.

\section{Testing the hypothesised relationships}

Table 3 shows that five $p$-values in the proposed employee engagement and turnover intention structural model were statistically significant. The strength of the influence of $\xi_{j}$ and/or $\eta_{j}$ on $\eta_{i}$ was substantial and significant between proactive personality and job crafting ( $p=0.73$; accept Hypothesis 1); job crafting and meaningful work ( $p=0.34$; accept Hypothesis 3 ); meaningful work and employee engagement ( $p=0.67$; accept Hypothesis 4$)$; job crafting and employee engagement $(p=0.29$; accept Hypothesis 6); and employee engagement and turnover intention ( $p=-0.50$; accept Hypothesis 8$)$ at the 95\% confidence level.

Three $p$-values were not statistically significant. The strength of the influence of $\xi_{j}$ and / or $\eta_{j}$ on $\eta_{i}$ was not substantial and significant between proactive personality and turnover intention ( $p=0.12$; reject Hypothesis 2); meaningful work and turnover intention ( $p=-0.01$; reject Hypothesis 5$)$; and employee engagement and job crafting $(p=0.05$; reject Hypothesis 7) at the 95\% confidence level.

\section{Partial least squares path analysis}

Before commencing with PLS SEM, the proposed employee engagement and turnover intention structural model was modified. As shown in Figure 2, the revised structural model excluded the hypothesised positive influence of employee engagement on job crafting. Hypothesis 7 could, therefore, not be tested during PLS SEM because of the model modification.

\section{Reliability analysis}

A reliability analysis was done on all the latent variable scales that were included in the web-based survey. Table 4 shows 
TABLE 4: Analysis of the partial least squares path model.

\begin{tabular}{lccc}
\hline Scale & Average variance extracted & Composite reliability & $\boldsymbol{R}^{\mathbf{2}}$ \\
\hline PP & 0.54 & 0.87 & - \\
JC & 0.49 & 0.79 & 0.35 \\
MW & 0.78 & 0.95 & 0.11 \\
EE & 0.81 & 0.93 & 0.57 \\
TI & 0.69 & 0.90 & 0.21 \\
\hline
\end{tabular}

PP, proactive personality; JC, job crafting; MW, meaningful work; EE, employee engagement; $\mathrm{Tl}$, turnover intention.

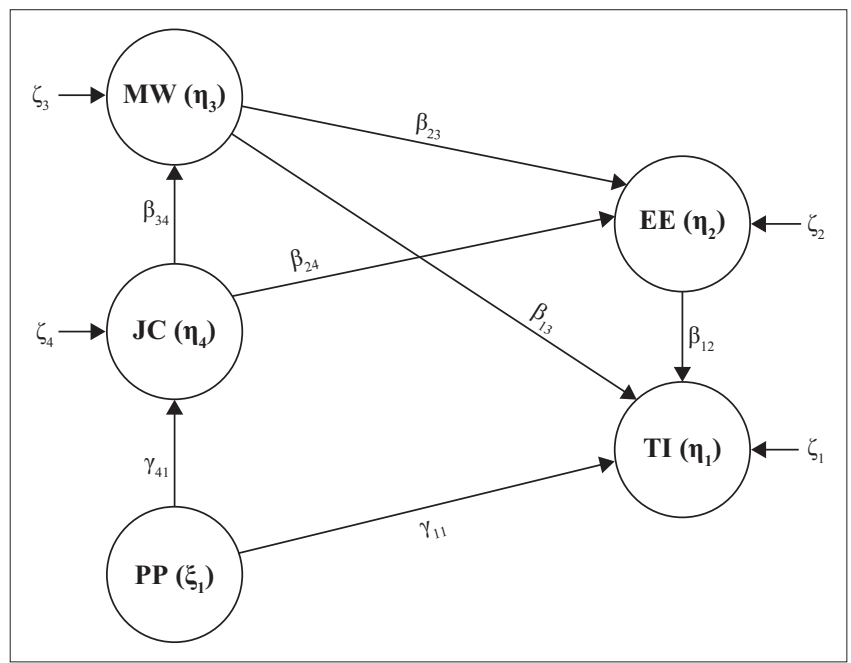

Note: It was assumed that the structural error terms were fixed to zero.

$\xi_{1}$, proactive personality; $\eta_{1^{\prime}}$ turnover intention; $\eta_{2^{\prime}}$ employee engagement; $\eta_{3^{\prime}}$, meaningful work; $\eta_{4}$, job crafting.

FIGURE 2: Revised employee engagement and turnover intention structural model.

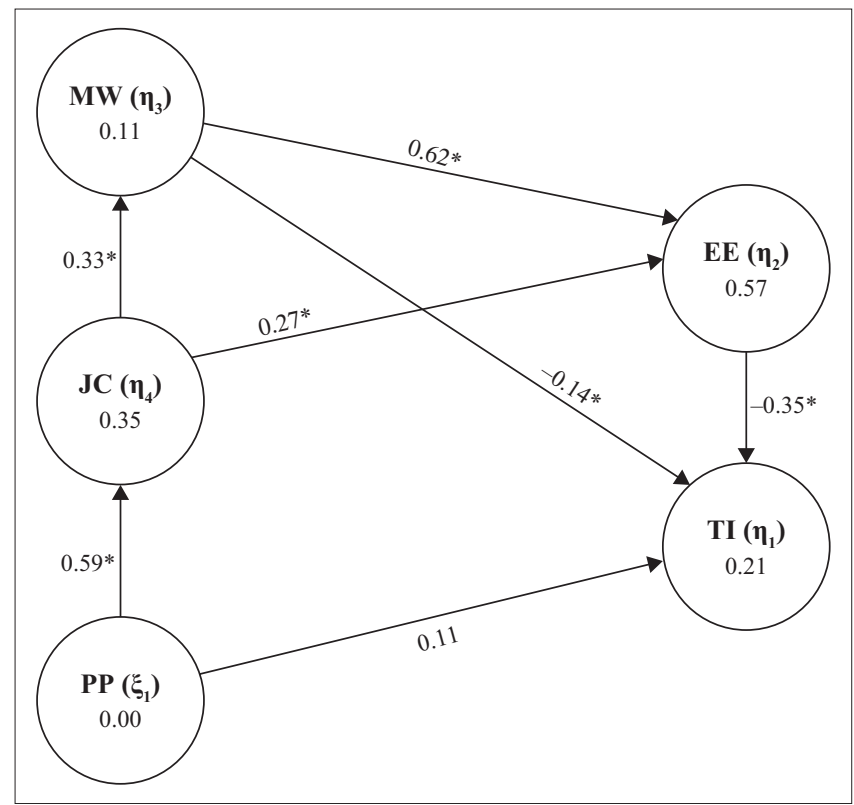

*, significant path; $\xi_{1}$, proactive personality; $\eta_{1}$, turnover intention; $\eta_{2}$, employee engagement; $\eta_{3}$, meaningful work; $\eta_{4}$, job crafting.

FIGURE 3: Partial least squares report for the revised employee engagement and turnover intention structural model.

that the composite reliability $(>0.70)$ and average variance extracted $(>0.50)$ obtained for the latent variable scales were satisfactory. It was concluded that the outer-measurement model fit was satisfactory. Each latent variable scale measured the construct it was assigned to measure.

\section{Testing the structural model}

Table 4 shows that the $R^{2}$ values of employee engagement (0.57) and turnover intention (0.21) were satisfactory. By implication, the inner-model measurement fit was satisfactory. The latent variables in the revised employee engagement and turnover intention structural model explained $57 \%$ of variance in employee engagement and $21 \%$ of variance in turnover intention.

Figure 3 depicts the path coefficients between the latent variables of interest. Six path coefficients in the revised employee engagement and turnover intention structural model were statistically significant. The strength of the influence of $\xi_{j}$ and/or $\eta_{j}$ on $\eta_{i}$ was substantial and significant between proactive personality and job crafting (accept Hypothesis 1); job crafting and meaningful work (accept Hypothesis 3); meaningful work and employee engagement (accept Hypothesis 4); meaningful work and turnover intention (accept Hypothesis 5); job crafting and employee engagement (accept Hypothesis 6); and employee engagement and turnover intention (accept Hypothesis 8) at the 95\% confidence level.

One path coefficient was not statistically significant. The strength of the influence of $\xi_{j}$ and/or $\eta_{j}$ on $\eta_{i}$ was not substantial and significant between proactive personality and turnover intention (reject Hypothesis 2) at the 95\% confidence level.

\section{Discussion}

The researchers drew on the central tenets of the JD-R theory to examine the role of job crafting, proactive personality (i.e. a personal resource) and meaningful work (i.e. a job resource) in predicting employee engagement and turnover intention among employees in service-providing firms that operate in the financial services industry. Results showed that employees exhibit average levels of employee engagement and turnover intention. It is, therefore, necessary to develop and implement human resource practices and interventions that concentrate on addressing employee disengagement and turnover intention.

Research has directed attention to a number of antecedents of variance in employee engagement and turnover intention. However, in response to recent developments in job crafting and proactive personality literature, only meaningful work, job crafting and proactive personality were addressed within the scope of the study. The researchers hypothesised that employees who have a proactive personality would be more inclined to exhibit crafting behaviour. This, in turn, may contribute to the meaningfulness of work-related activities, foster employee engagement and discourage the development of turnover intention.

Results generally supported the hypothesised relationships. Covariance-based SEM showed that hypotheses 1, 3, 4, 6 and 8 were statistically significant, and hypotheses 2,5 and 7 were not statistically significant. Results of PLS SEM were mostly consistent with the results of covariance-based SEM. 
Partial least squares SEM showed that hypotheses 1, 3, 4, 5, 6 and 8 were statistically significant, and Hypothesis 2 was not statistically significant. As mentioned, Hypothesis 7 could not be tested during PLS SEM because of the model modification. The only difference in the results of covariancebased SEM and PLS SEM related to Hypothesis 5. In summary, results revealed that proactive personality was positively related to employee engagement and negatively related to turnover intention through job crafting and meaningful work.

Unexpectedly, the hypothesised positive influence of proactive personality on turnover intention was not statistically significant. Covariance-based SEM $(p=0.12)$ and PLS SEM (PLS path coefficient $=0.11$ ) demonstrated that proactive personality was not a predictor of turnover intention. By drawing on the results obtained for Hypothesis 1 $(p=0.73$; PLS path coefficient $=0.59)$, the researchers argued that employees who have a proactive personality rather exhibit crafting behaviour when their need for congruence is not met by their current work environment, as opposed to seeking alternative employment opportunities (i.e. turnover intention).

\section{Practical implications}

The practical implications of the study are threefold. Firstly, covariance-based SEM and PLS SEM demonstrated that job crafting is a predictor of meaningful work ( $p=0.34$; PLS path coefficient $=0.33$ ), as well as employee engagement $(p=0.29$; PLS path coefficient $=0.27)$. It is, therefore, necessary to encourage crafting behaviour among employees in the financial services industry in order to contribute to the meaningfulness of work-related activities and to foster employee engagement. The antecedents of job crafting can broadly be divided into individual differences (e.g. psychological states and personality traits) and organisational factors (e.g. organisational climate and supervisory support) (Petrou, 2013). The researchers recommend that at an individual level, human resource practices and interventions should be tailored to recruit and select employees who are more inclined to exhibit crafting behaviour. At an organisational level, supervisors should cultivate an organisational climate that encourages job crafting. In addition, supervisors should model crafting behaviours to their subordinates.

Secondly, covariance-based SEM $(p=0.73)$ and PLS SEM (PLS path coefficient $=0.59$ ) demonstrated that proactive personality is a predictor of job crafting. It is, therefore, necessary to encourage proactivity among employees in the financial services industry in order to foster job crafting. Theories of proactivity suggest that the antecedents of proactivity can broadly be separated into individual differences (e.g. knowledge, skills and abilities and personality traits), motivational forces (e.g. extrinsic motivation and role-based motivation) and organisational factors (e.g. organisational climate and supervisory support) (Strauss \& Parker, 2014). At an individual level, human resource practices and interventions should be tailored to recruit and select employees who are more inclined to be 'self-starting and change-orientated to enhance personal and organisational effectiveness' (Unsworth \& Parker, 2003, p. 178). In addition, human resources practitioners should implement developmental interventions that equip employees with the knowledge, skills and abilities required for proactivity. At a motivational level, it is important to recognise and reward employees who exhibit proactivity. Recognising and rewarding employees who exhibit proactivity, will reinforce its value. Lastly, at an organisational level, supervisors should cultivate an organisational climate that encourages proactivity (McCormick et al., 2018).

Thirdly, covariance-based SEM $(p=0.67)$ and PLS SEM (PLS path coefficient $=0.62$ ) demonstrated that meaningful work is a predictor of employee engagement. In addition, PLS SEM (PLS path coefficient $=-0.14$ ) demonstrated that meaningful work is a predictor of turnover intention. It is, therefore, necessary to improve the meaningfulness of work in organisations in the financial services industry in order to foster employee engagement and to discourage the development of turnover intention. As mentioned, job design (e.g. task significance and comprehensibility), person-job fit (e.g. values and mission), work relationships (e.g. colleagues and supervisors) and work beliefs (e.g. calling orientation) contribute to the meaningfulness of work-related activities (Pratt \& Ashforth, 2003). With this in mind, the researchers recommend that human resources practitioners draw on the Job Characteristics theory (Hackman \& Oldham, 1976) in order to improve the meaningfulness of employees' workrelated activities through job enrichment. In addition, it is recommended that human resource practices and interventions be tailored to consider person-job fit and work beliefs when recruiting and selecting employees.

\section{Limitations of the study and recommendations for research}

Although the study offers valuable insight into the relationships between job crafting, proactive personality, meaningful work, employee engagement and turnover intention, it is not without limitations. The most noteworthy limitation of the study is its cross-sectional survey design. This design prevents the examination of causal relationships between latent variables and additional (including longitudinal) research is needed to understand the interplay and relational dynamics between the latent variables.

Another limitation relates to the nature of self-reported measures. Owing to the use of self-report measures, it is plausible that common-method variance negatively affected the accuracy of associations between the latent variables of interest. Reasonable steps were, however, taken to assure participants of the complete protection of their identity in order to reduce evaluation apprehension and, as a consequence, common-method variance (Podsakoff, MacKenzie, Lee, \& Podsakoff, 2003). Nonetheless, multiple-source studies are needed to fully understand how job crafting, proactive 
personality and meaningful work influence employee engagement and turnover intention.

The mean age of respondents was 26.53 years old, and $34 \%$ of participants had been employed for less than a year at their current service-providing firm. Research has revealed that demographic characteristics, such as age and organisational tenure, influence employee engagement (Berg, Wrzesniewski, \& Dutton, 2010) and turnover intention (Peltokorpi, Allen, \& Froese, 2015). Although the sample size of the study was satisfactory, it is recommended that the study should be replicated among a sample with broader representation in terms of age and organisational tenure. Similarly, women comprised $61 \%$ of the sample. While research concerning the association between gender and proactivity has not been conclusive (Berdicchia, Nicolli, \& Masino, 2016), it is recommended that future studies explore the salience of gender.

The four subscales of the Job Crafting Scale (Tims et al., 2012) were combined to obtain a composite measurement of crafting behaviour among participants. Research is needed to understand how each type of job crafting (i.e. increasing social or structural job resources and challenging job demands, and decreasing hindering job demands) is related to proactive personality, meaningful work and employee engagement. In addition, job crafting was operationalised as an individual-level phenomenon. It would, however, be valuable to investigate how the opportunity to perform crafting behaviours, as well as the effects of job crafting, may be influenced by other individuals such as colleagues and supervisors (Bakker, Rodríguez-Muñoz, \& Sanz Vergel, 2016; Tims, Bakker, Derks, \& Van Rhenen, 2013). Research which operationalises job crafting as a team-level phenomenon is needed.

The demarcation of the study within the financial services industry limits the findings and conclusions to the context of organisations within this industry. Research is needed to determine whether results obtained in the study hold true in other occupational contexts in order to generalise results to other work environments.

\section{Concluding remarks}

The study illustrates that the central tenets of JD-R theory can be applied to employees in the financial services industry to address challenges regarding employee engagement and turnover intention. Results demonstrated that job crafting, proactive personality and meaningful work significantly predict variance in employee engagement, which in turn significantly predicts turnover intention along with meaningful work. Employees with a proactive personality were more inclined to exhibit crafting behaviour to align job demands and job resources with their needs and abilities. By making their work more meaningful, these employees were more engaged in their work and, in turn, less inclined to develop turnover intention.

\section{Acknowledgements}

The authors are grateful for the support received from the service-providing firms that agreed to participate in the research study.

\section{Competing interests}

The authors declare that they have no financial or personal relationships which may have inappropriately influenced them in writing this article.

\section{Author's contributions}

N.V. conducted the literature review, facilitated the selfadministered web-based survey and prepared the manuscript. B.B. was the study leader of this project. M.K. facilitated the data processing.

\section{Funding}

This research received no specific grant from any funding agency in the public, commercial or not-for-profit sectors.

\section{Data availability statement}

New data were created and analysed in this study. Authors may be contacted in this regard.

\section{Disclaimer}

The views and opinions expressed in this article are those of the authors and do not necessarily reflect the official policy or position of any affiliated agency of the authors.

\section{References}

\footnotetext{
Alderfer, C. P. (1972). Existence, relatedness, and growth: Human needs in organizational settings. New York: Free Press.

Agarwal, U. A., \& Gupta, V. (2018). Relationships between job characteristics, work engagement, conscientiousness and managers' turnover intentions: A moderatedmediation analysis. Personnel Review, 47(2), 353-377. https://doi.org/10.1108/ PR-09-2016-0229

Arnoux-Nicolas, C., Sovet, L., Lhotellier, L., Di Fabio, A., \& Bernaud, J. L. (2016) Perceived work conditions and turnover intentions: The mediating role of meaning of work. Frontiers in Psychology, 7, 704-713. https://doi.org/10.3389/ fpsyg.2016.00704

Bakker, A. B., Hakanen, J. J., Demerouti, E., \& Xanthopoulou, D. (2007). Job resources boost work engagement, particularly when job demands are high. Journal of Educational Psychology, 99(2), 274-284. http://doi.org/10.1037/0022-0663.99.2.274

Bakker, A. B. (2011). An evidence-based model of work engagement. Current Directions in Psychological Science, 20(4), 265-269. https://doi.org/10.1177/0963721411414534

Bakker, A. B., \& Demerouti, E. (2014). Job demands-resources theory. In P. Y. Chen \& C. L. Cooper (Eds.), Wellbeing: A complete reference guide: Work and wellbeing (vol. 3, pp. 37-64). Chichester: Wiley-Blackwell. https://doi.org/10.1002/9781118 539415.wbwell019

Bakker, A. B., Rodríguez-Muñoz, A., \& Sanz Vergel, A. I. (2016). Modelling job crafting behaviours: Implications for work engagement. Human Relations, 69(691) 169-189. https://doi.org/10.1177/0018726715581690

Bakker, A. B., Tims, M., \& Derks, D. (2012). Proactive personality and job performance: The role of job crafting and work engagement. Human Relations, 65(10), 1359-1378. https://doi.org/10.1177/0018726712453471

Barrick, M. R., Mount, M. K., \& Li, N. (2013). The theory of purposeful work behavior: The role of personality, higher-order goals, and job characteristics. Academy of Management Review, 38(1), 132-153. https://doi.org/10.5465/ amr.2010.0479

Bateman, T. S., \& Crant, J. M. (1993). The proactive component of organizational behavior: A measure and correlates. Journal of Organizational Behavior, 14(2), 103-118. https://doi.org/10.1002/job.4030140202

Berdicchia, D., Nicolli, F., \& Masino, G. (2016). Job enlargement, job crafting and the moderating role of self-competence. Journal of Managerial Psychology, 31(2), 318-330. https://doi.org/10.1108/JMP-01-2014-0019
} 
Berg, J. M., Wrzesniewski, A., \& Dutton, J. E. (2010). Perceiving and responding to challenges in job crafting at different ranks: When proactivity requires adaptivity. Journal of Organizational Behavior, 31(2-3), 158-186. https://doi.org/10.1002/ job. 645

Chang, W. J. A., Wang, Y. S., \& Huang, T. C. (2013). Work design-related antecedents of turnover intention: A multilevel approach. Human Resource Management, 52(1) 1-26. https://doi.org/10.1002/hrm.21515

Claes, R., Beheydt, C., \& Lemmens, B. (2005). Unidimensionality of abbreviated proactive personality scales across cultures. Applied Psychology, 54(4), 476-489. proactive personality scales across cultures. Applied $P$

Clark, L. A., \& Watson, D. (1995). Constructing validity: Basic issues in objective scale development. Psychological Assessment, 7(3), 309-319. https://doi.org/10.1037/ 1040-3590.7.3.309

Crant, J. M. (1995). The proactive personality scale and objective job performance among real estate agents. Journal of Applied Psychology, 80(4), 532-537. https:// doi.org/10.1037/0021-9010.80.4.532

Demerouti, E., \& Bakker, A. B. (2011). The Job Demands-Resources model: Challenges for future research. South African Journal of Industrial Psychology, 37(2), 1-9. https://doi.org/10.4102/sajip.v37i2.974

Demerouti, E., Bakker, A. B., Nachreiner, F., \& Schaufeli, W. B. (2001). The Job Demands-Resources model of burnout. Journal of Applied Psychology, 86(3), 499-512. https://doi.org/10.1037//0021-9010.86.3.499

Fredrickson, B. L. (2004). The broaden-and-build theory of positive emotions. Philosophical Transactions of the Royal Society B: Biological Sciences, 359, 1367-1377. https://doi.org/10.1098/rstb.2004.1512

Fritz, C., \& Sonnentag, S. (2009). Antecedents of day-level proactive behavior: A look at job stressors and positive affect during the workday. Journal of Management 35(1), 94-111. https://doi.org/10.1177/0149206307308911

Gabel Shemueli, R., Dolan, S. L., Suárez Ceretti, A., \& Nuñez Del Prado, P. (2016) Burnout and engagement as mediators in the relationship between work characteristics and turnover intentions across two lbero-American nations. Stress and Health, 32(5), 597-606. https://doi.org/10.1002/smi.2667

Geldenhuys, M., Laba, K., \& Venter, C. M. (2014). Meaningful work, work engagement and organisational commitment. South African Journal of Industrial Psychology, 40(1), 1-10. https://doi.org/10.4102/sajip.v40i1.1098

Hackman, J. R., \& Oldham, G. R. (1976). Motivation through the design of work: Test of a theory. Organizational Behavior and Human Performance, 16(2), 250-279. https://doi.org/10.1016/0030-5073(76)90016-7

Hakanen, J. J., Bakker, A. B., \& Schaufeli, W. B. (2006). Burnout and work engagement among teachers. Journal of School Psychology, 43(6), 495-513. https://doi. org/10.1016/j.jsp.2005.11.001

Hakanen, J. J., Peeters, M. C., \& Schaufeli, W. B. (2018). Different types of employee well-being across time and their relationships with job crafting. Journal of Occupational Health Psychology, 23(2), 289-301. https://doi.org/10.1037/ ocp0000081

Halbesleben, J. R. B. (2010). A meta-analysis of work engagement: Relationships with burnout, demands, resources, and consequences. In A. B. Bakker \& M. P. Leiter (eds.) Work engagement: A handbook of essential theory and research (pp. 102-117) New York: Psychology Press.

Harju, L. K., Hakanen, J. J., \& Schaufeli, W. B. (2016). Can job crafting reduce job boredom and increase work engagement? A three-year cross-lagged panel study. Journal of Vocational Behavior, 95-96, 11-20. https://doi.org/10.1016/j. jvb.2016.07.001

Hobfoll, S. E. (1989). Conservation of resources: A new attempt at conceptualizing stress. American Psychologist, 44(3), 513-524. https://doi.org/10.1037/0003 066X.44.3.513

Hyvönen, K., Feldt, T., Salmela-Aro, K., Kinnunen, U., \& Mäkikangas, A. (2009). Young managers' drive to thrive: A personal work goal approach to burnout and work engagement. Journal of Vocational Behavior, 75(2), 183-196. https://doi.org/ 10.1016/j.jvb.2009.04.002

Janik, M., \& Rothmann, S. (2015). Meaningful work and secondary school teachers' intention to leave. South African Journal of Education, 35(2), 1-13. https://doi. org/10.15700/SAJE.V35N2A1008

Jung, H. S., \& Yoon, H. H. (2016). What does work meaning to hospitality employees? The effects of meaningful work on employees' organizational commitment: The mediating role of job engagement. International Journal of Hospitality Management, 53, 59-68. https://doi.org/10.1016/j.ijhm.2015.12.004

Macey, W. H., Schneider, B., Barbera, K. M., \& Young, S. A. (2009). Employee engagement: Tools for analysis, practice, and competitive advantage (vol. 31). Chichester: Wiley-Blackwell.

Mäkikangas, A. (2018). Job crafting profiles and work engagement: A person-centered approach. Journal of Vocational Behavior, 106, 101-111. https://doi.org/10.1016/ j.jvb.2018.01.001

May, D. R., Gilson, R. L., \& Harter, L. M. (2004). The psychological conditions of meaningfulness, safety and availability and the engagement of the human spirit at work. Journal of Occupational and Organizational Psychology, 77(1), 11-37. https://doi.org/10.1348/096317904322915892

McCormick, B. W., Guay, R. P., Colbert, A. E., \& Stewart, G. L. (2018). Proactive personality and proactive behaviour: Perspectives on person-situation interactions. Journal of Occupational and Organizational Psychology, 92(1), 30-51. https://doi.org/10.1111/joop.12234

Mezirow, J. (1981). A critical theory of adult learning and education. Adult Education Quarterly, 32(1), 3-24. https://doi.org/10.1177/074171368103200101
Molden, D. C., \& Dweck, C. S. (2006). Finding 'meaning' in psychology: A lay theories approach to self-regulation, social perception and social development American Psychologist, 61(3), 192-203. https://doi.org/10.1037/0003-066X.61.3.192

Moore, J. E. (2000). One road to turnover: An examination of work exhaustion in technology professionals. MIS Quarterly, 24(1), 141-168. https://doi.org/10.2307/ 3250982

Nunnally, J. (1978). Psychometric methods. New York: McGraw-Hill.

Parker, P. D., \& Martin, A. J. (2009). Coping and buoyancy in the workplace: Understanding their effects on teachers' work-related well-being and engagement. Teaching and Teacher Education, 25(1), 68-75. https://doi.org/10.1016/j. tate.2008.06.009

Parker, S. K., \& Collins, C. G. (2010). Taking stock: Integrating and differentiating multiple proactive behaviors. Journal of Management, 36(3), 633-662. https:// doi.org/10.1177/0149206308321554

Parker, S. K., \& Ohly, S. (2008). Designing motivating jobs: An expanded framework for linking work characteristics and motivation. In R. Kanfer, G. Chen, \& R. D. Pritchard (Eds.), Work motivation: Past, present, and future (pp. 233-284). New York: Routledge.

Peltokorpi, V., Allen, D. G., \& Froese, F. (2015). Organizational embeddedness, turnover intentions, and voluntary turnover: The moderating effects of employee demographic characteristics and value orientation. Journal of Organizational Behavior, 36(2), 292-312. https://doi.org/10.1002/job.1981

Petrou, P. (2013). Crafting the change: The role of job crafting and regulatory focus in adaption to organizational change. Unpublished doctoral dissertation. Utrecht, NL: Utrecht University.

Plomp, J., Tims, M., Akkermans, J., Khapova, S. N., Jansen, P. G. W., \& Bakker, A. B. (2016). Career competencies and job crafting: How proactive employees influence their well-being. Career Development International, 21(6), 587-602. https://doi. org/10.1108/CDI-08-2016-0145

Podsakoff, P. M., MacKenzie, S. B., Lee, J. Y., \& Podsakoff, N. P. (2003). Common method biases in behavioral research: A critical review of the literature and recommended remedies. Journal of Applied Psychology, 88(5), 879-903. https:// doi.org/10.1037/0021-9010.88.5.879

Pratt, M. G., \& Ashforth, B. E. (2003). Fostering meaningfulness in working and at work. In K. S. Cameron, J. E. Dutton, \& R. E. Quinn (Eds.), Positive organizational scholarship: Foundations of a new discipline (pp. 309-327). San Francisco, CA: Berrett-Koehler Publishers.

Price, J. L. (2001). Reflections on the determinants of voluntary turnover. Internationa Journal of Manpower, 22(7), 600-624. https://doi.org/10.1108/EUM00000 00006233

Rich, B. L., LePine, J. A., \& Crawford, E. R. (2010). Job engagement: Antecedents and effects on job performance. Academy of Management Journal, 53(3), 617-635. https://doi.org/10.5465/AMJ.2010.51468988

Roberts, B. W., Luo, J., Briley, D. A., Chow, P. I., Su, R., \& Hill, P. L. (2017). A systematic review of personality trait change through intervention. Psychological Bulletin 143(2), 117-141. https://doi.org/10.1037/bul0000088

Saks, A. M. (2019). Antecedents and consequences of employee engagement revisited. Journal of Organizational Effectiveness: People and Performance, 6(1) 19-38. https://doi.org/10.1108/JOEPP-06-2018-0034

Schaufeli, W. B., Bakker, A. B., \& Salanova, M. S. (2006). The measurement of work engagement with a short questionnaire: A cross-national study. Educational and Psychological Measurement, 66(4), 701-716. https://doi.org/10.1177/0013164 405282471

Schaufeli, W. B., Salanova, M. S., González-Romá, V. A., \& Bakker, A. B. (2002). The measurement of engagement and burnout: $A$ two sample confirmatory factor analytic approach. Journal of Happiness Studies, 3(1), 71-92. https://doi.org/ 10.1023/A:1015630930326

Schaufeli, W. B., \& Van Rhenen, W. (2006). About the role of positive and negative emotions in managers' well-being: A study using the Job-related Affective Wellbeing Scale (JAWS). Gedrag \& Organisatie, 19(4), 223-244.

Shuck, B. (2019). Does my engagement matter? In Yeoman, R., Bailey, C., Madden, A., \& Thompson, M. (eds.), The Oxford handbook of meaningful work (pp. 288-301). New York: Oxford University Press.

Sonnentag, S. (2003). Recovery, work engagement, and proactive behavior: A new look at the interface between nonwork and work. Journal of Applied Psychology, 88(3), 518-528. https://doi.org/10.1037/0021-9010.88.3.518

Steger, M. F., Dik, B. J., \& Duffy, R. D. (2012). Measuring meaningful work: The Work and Meaning Inventory (WAMI). Journal of Career Assessment, 20(3), 322-337. https://doi.org/10.1177/1069072711436160

Steger, M. F., Littman-Ovadia, H., Miller, M., Menger, L., \& Rothmann, S. (2013). Engaging in work even when it is meaningless. Journal of Career Assessment, 21(2), 348-361. https://doi.org/10.1177/1069072712471517

Strauss, K., \& Parker, S. K. (2014). Effective and sustained proactivity in the workplace: A self-determination theory perspective. In M. Gagné (ed.), The Oxford handbook of work engagement, motivation, and self-determination theory (pp. 50-71). New York: Oxford University Press.

Sun, J., Lee, J. W., \& Sohn, Y. W. (2019). Work context and turnover intention in socia enterprises: The mediating role of meaning of work. Journal of Manageria Psychology, 34(1), 46-60. https://doi.org/10.1108/JMP-11-2017-0412

Takawira, N., Coetzee, M., \& Schreuder, D. (2014). Job embeddedness, work engagement and turnover intention of staff in a higher education institution: An exploratory study. South African Journal of Human Resource Management, 12(1), 1-10. https://doi.org/10.4102/sajhrm.v12i1.524 
Tims, M., \& Bakker, A. B. (2010). Job crafting: Towards a new model of individual job redesign. South African Journal of Industrial Psychology, 36(2), 1-9. https://doi. org/10.4102/sajip.v36i2.841

Tims, M., Bakker, A. B., \& Derks, D. (2012). Development and validation of the Job Crafting Scale. Journal of Vocational Behavior, 80(1), 173-186. https://doi.org/ 10.1016/j.jvb.2011.05.009

Tims, M., Bakker, A. B., Derks, D., \& Van Rhenen, W. (2013). Job crafting at the team and individual level: Implications for work engagement and performance. Group \& Organization Management, 38(4), 427-454. https://doi.org/10.1177/1059601 113492421

Tims, M., Derks, D., \& Bakker, A. B. (2016). Job crafting and its relationships with person-job fit and meaningfulness: A three-wave study. Journal of Vocational Behavior, 92, 44-53. https://doi.org/10.1016/j.jvb.2015.11.007

Unsworth, K. L., \& Parker, S. K. (2003). Proactivity and innovation: Promoting a new workforce for the new workplace. In D. Holman, T. D. Wall, C. W. Clegg, P. Sparrow, \& A. Howard (eds.), The new workplace: A guide to the human impact of modern working practices (pp. 175-196). Chichester: John Wiley \& Sons.
Wrzesniewski, A. (2003). Finding positive meaning in work. In K. S. Cameron, J. E. Dutton, \& R. E. Quinn (Eds.), Positive organizational scholarship: Foundation of a new discipline (pp. 296-308). San Francisco, CA: Berrett-Koehler Publishers.

Wrzesniewski, A., \& Dutton, J. E. (2001). Crafting a job: Revisioning employees as active crafters of their work. Academy of Management Review, 26(2), 179-201. https://doi.org/10.5465/AMR.2001.4378011

Wrzesniewski, A., LoBuglio, N., Dutton, J. E., \& Berg, J. M. (2013). Job crafting and cultivating positive meaning and identity in work. In A. B. Bakker (Ed.), Advances in positive organizational psychology (pp. 281-302). Bingley: Emerald. http://dx. doi.org/10.1108/S2046-410X(2013)0000001015

Wrzesniewski, A., McCauley, C., Rozin, P., \& Schwartz, B. (1997). Jobs, careers, and callings: People's relations to their work. Journal of Research in Personality, 31(1) 21-33. https://doi.org/10.1006/jrpe.1997.2162

Xanthopoulou, D., Bakker, A. B., Demerouti, E., \& Schaufeli, W. B. (2007). The role of personal resources in the Job Demands-Resources model. International Journal of Stress Management, 14(2), 121-141. https://doi.org/10.1037/1072-5245.14.2.121

Zhang, L., Lu, H., \& Li, F. (2018). Proactive personality and mental health: The role of job crafting. PsyCh Journal, 7(3), 154-155. https://doi.org/10.1002/pchj.214 